\title{
THE ETHNOBOTANY OF BRYOPHYTES IN MEXICO
}

\section{LA ETNOBOTÁNICA DE BRIOFITAS EN MÉXICO}

\author{
@EnRique Hernández-RodrígueZ ${ }^{1 *}$, @Claudio Delgadillo-Moya
}

${ }^{1}$ Institut de Recherche sur les Forêts, Université du Québec en Abitibi-Témiscamingue, QC, Canada.

${ }^{2}$ Universidad Nacional Autónoma de México, Instituto de Biología, Cd. Mx., Mexico.

${ }^{*}$ Corresponding author: enrique.hernandezrodriguez@uqat.ca

\begin{abstract}
Background: Mexico has an extensive record of vascular plants that are used by humans and associated with traditional ecological knowledge (TEK). However, for non-vascular plants like bryophytes, there is no consensus on how many and which species have any TEK associated with them.
\end{abstract}

Questions: How many bryophyte species are used by humans in Mexico? What TEK is associated with them? Why is it important to document ethnobotanical information on bryophytes?

Studied species: Bryophytes sensu lato.

Study site and dates: Mexican territory. Time span covered by the studies reviewed was from 1552 to 2020.

Methods: Information in published materials, repositories, and personal fieldwork records were used to build a database on bryophyte taxa associated with some TEK in Mexico.

Results: According to available data, the bryophyte flora with some associated TEK in Mexico includes 36 species belonging to 30 genera and 23 families. The main use is ceremonial, although craft, environmental, medicinal, and ornamental uses are also reported.

Conclusions: This study updates the number of bryophytes used as non-forest timber resources. Ethnobotanical records for Mexico are among the highest in countries that use bryophytes in human enterprises.

Keywords: Ethnobryology, liverworts, mosses, non-vascular plants, traditional ecological knowledge.

\section{Resumen}

Antecedentes: México tiene un extenso registro de plantas vasculares que son utilizadas por humanos y que están asociadas con algún conocimiento ecológico tradicional (CET). Sin embargo, para las plantas no vasculares como las briofitas, no hay un consenso sobre cuántas y cuáles especies tienen algún CET asociado.

Preguntas: ¿Cuántas especies de briofitas son utilizadas por humanos en México? ¿Cuál es el CET asociado a ellas? ¿Por qué es importante documentar la información etnobotánica sobre las briofitas?

Especies de estudio: Briofitas sensu lato.

Sitio y años de estudio: Territorio mexicano. El período de tiempo cubierto por los estudios revisados fue de 1552 a 2020 .

Métodos: La información en trabajos publicados, repositorios y registros personales de trabajo de campo se utilizaron para construir una base de datos sobre taxones de briofitas con algún CET en México.

Resultados: De acuerdo con los datos disponibles, la flora de briofitas con algún CET en México comprende 36 especies en 30 géneros y 23 familias. El uso principal es ceremonial, aunque también se reportan usos artesanales, ambientales, medicinales y ornamentales.

Conclusiones: Este estudio actualiza el número de especies de briofitas utilizadas como recursos forestales no maderables. Los registros etnobotánicos para México están entre los más numerosos para los países que usan briofitas en su vida diaria.

Palabras clave: Conocimiento ecológico tradicional, etnobriología, hepáticas, musgos, plantas no vasculares. 
Traditional ecological knowledge (TEK) includes the understanding, innovations, and practices of indigenous and local communities throughout the world (Brush 1993, Berkes 1999). TEK is developed from experience over time, adapted to the local culture and environment, and is transmitted orally from generation to generation. It is collectively owned, and represented in stories, songs, folklore, cultural values, beliefs, rituals, community laws, local language and agricultural practices, including the production of plant and animal species (Berkes et al. 2000, CBD 2020). Traditional knowledge of bryophytes (mosses, liverworts, and hornworts) has been reported around the world but is often neglected (Berkes 1993, Harris 2008) in formal research. The study of the relationship between humans and these non-vascular plants is called ethnobryology (Flowers 1957). However, this term is not often used in ethnobiology, perhaps because there are few studies on bryophytes (Harris 2008). According to the last author, there are around 150 bryophyte species of ethnobotanical interest recorded worldwide. The highest number of reports have been made from such countries as China, India, the United States, and Canada; the most common ethnobotanical use for bryophytes is for medicinal purposes (Harris 2008, Alam 2016). Numerous examples are cited by Glime (2017b).

Mexico is one of the countries with the highest biological and cultural diversity in the world (Sarukhán et al. 2009, Toledo et al. 2019). About $25 \%$ of the vascular plant species (approximately 7,461 species) are used in traditional ways (Mapes \& Basurto 2016). Thus, the flora is an essential part of traditions and customs in many regions of the country. Nevertheless, bryophytes are usually neglected in ethnobotanical studies about traditional knowledge.

Recent estimations report 1,591 species of bryophytes living in different ecosystems in Mexico (Delgadillo 2014, Delgadillo \& Juárez-Martínez 2014, Ellis et al. 2018, Escolástico-Ortíz \& Juárez-Martínez 2018). Use of bryophytes has been documented since about 500 years for medicinal purposes and 180 years for religious purposes (De la Cruz 1552, Calderón de la Barca 1843); however, it is likely that they were also used in pre-Columbian times. Harris (2008) indicated that four species are used for handicrafts, and Delgadillo \& Cárdenas (1990) reported the use of at least three moss species that are sold during the Christmas season. However, there is no consensus on which species are used and what their associated TEK is in different regions of Mexico. This study seeks to answer the following questions: how many bryophyte species are used by humans in Mexico? Is there any TEK associated with them? Specifically, the work intends 1) to obtain a checklist of useful bryophytes, including their use or associated TEK, and 2) to discuss the importance of these results for ethnobotany and for bryophyte conservation in Mexico.

Recording TEK associated with bryophytes updates knowledge of the use of non-timber forest resources, especially for a neglected group of plants. This work also seeks to stimulate the inclusion of bryophytes in ethnobotanical studies in Mexico, and in other countries with high biocultural diversity.

\section{Materials and methods}

The literature review searched for peer-reviewed articles and books in the Scopus and Google Scholar databases. Keywords included "bryophytes or moss or liverwort or hornwort" and "ethnobotany or traditional uses or traditional ecological knowledge or traditional knowledge or non-timber forest resources" (in English and Spanish) somewhere in the document. To obtain most records, all available works to date (2020) were considered. The Ethnobotanical Database of Plants of Mexico (BADEPLAM; Caballero \& Cortés 1982-2020), the Digital Library of Traditional Mexican Medicine (Zolla \& Argueta 2009), and the Herbarium of Medicinal Plants of the Mexican Institute of Social Security were reviewed. Also, personal records obtained between 2008 and 2017 in the state of Oaxaca, specifically in the municipalities of Ixtlán de Juárez $\left(\begin{array}{llllllll}17^{\circ} & 19^{\prime} & 51^{\prime \prime} & \mathrm{N}, 96^{\circ} & 29^{\prime} & 15^{\prime \prime} & \mathrm{W}\end{array}\right)$, Santiago Comaltepec ( $\left.17^{\circ} 33^{\prime} 57^{\prime \prime} \mathrm{N}, 96^{\circ} 32^{\prime} 54^{\prime \prime} \mathrm{W}\right)$, and Miahuatlán de Porfirio Díaz $\left(16^{\circ} 19^{\prime} 33^{\prime \prime} \mathrm{N}, 96^{\circ} 35^{\prime} 31^{\prime \prime}\right.$ W) were included. Personal records included species sampled for taxonomic determination; these were compared against specimens at MEXU.

The data were organized in a spreadsheet that included names of taxa, source document, and recorded locality. Local common names in native or indigenous languages were included, as well as an English and Spanish translation when possible. Traditional uses were arranged according to the classification by Bernal-Ramírez et al. (2019) which considers nine categories that are applicable to bryophytes: food, environmental, crafts, ceremonial, construction, fuel, medicinal, ornamental, and veterinary. Species sold during the Christmas season (Anastacio-Martínez et al. 2017a, $\underline{b}$, Martínez-López et al. 2017), were classified in the "ceremonial" category.

Moss nomenclature was updated according to a revised version of LATMOSS (Delgadillo 2010) and for families based on Goffinet \& Buck (2020); for liverworts and hornworts the classification accepted by Söderström et al. (2016) was followed. A TEK map showing the distribution of reports for bryophytes in Mexico was prepared. 


\section{Results}

Few publications document TEK and use of bryophytes in Mexico ( 30). Based on these references, the southern states contribute most records, particularly Oaxaca (15), Puebla (10), and Michoacán (8) (Figure 1). Mexican bryophytes with a use and TEK included 36 species in 30 genera and 23 families (Appendix 1, Figure 2). Literature on Mexican bryophytes does not report use as food, fuel, construction, or veterinary medicine. Mosses are the group with most uses (29), whereas liverworts only contributed 3 species. No references included information on hornworts.

The most relevant use of bryophytes is ceremonial during the Christmas period, though it is not the only religious activity where they are used. The mosses Thuidium delicatulum (Hedw.) Schimp., Hypnum amabile (Mitt.) Hampe, Dendropogonella rufescens (Schimp.) E. Britton, and those in the genera Dicranum and Campylopus, were mostly used for this purpose over the last five decades. Other uses, including TEK, such as crafts, environmental, medicinal, and ornamental have also been documented (Appendix 1, Table 1). Results include native language names of species, but also generic names, to identify mosses as a group (Table 2). In some native languages, bryophytes are classified locally based on the substrates where they grow (Table 3). These languages include Huastec, Maya, Mixe, Nahuatl, Popoluca, Seri, Tarahumara, Totonac, Tzeltal, and Zapotec (Appendix 1, Tables 1- $\underline{3}$ ).

\section{Discussion}

This study reports 36 species of bryophytes with their use or TEK. These results place Mexico among the countries with the highest number of ethnobryological records, third only to China (63 spp.) and India (58 spp.), and with a similar number as the United States (Harris 2008). Most reports come from areas with high biological diversity, humidity, and ethnic group's presence such as the states of Oaxaca and Chiapas. This relationship agrees with Toledo's $\underline{(1990}, \underline{2019)}$ suggestion regarding the presence of greater traditional knowledge in bio-culturally diverse areas. Species richness and lush growth in mild climates, however, are conditions that undoubtedly have favored and given ample opportunity for human interaction with potentially useful bryophyte species in certain areas of Mexico.

A traditional classification of mosses is reported for Chiapas, in Tzeltal and Maya languages, according to the substrate in which they grow (Berlin et al. 1974, Delgadillo 2000). In other regions of Mexico, there are traditional generic names that include liverworts and some lichens (Table 2) (Felger \& Moser 1985, Luna-José \& RendónAguilar 2012). However, the translation of these terms refers to "moss" because it is the closest word to describe these cryptogams due to similarity in growth form, size, and appearance. Bryophytes may have different generic names within the same native language, possibly due to linguistic

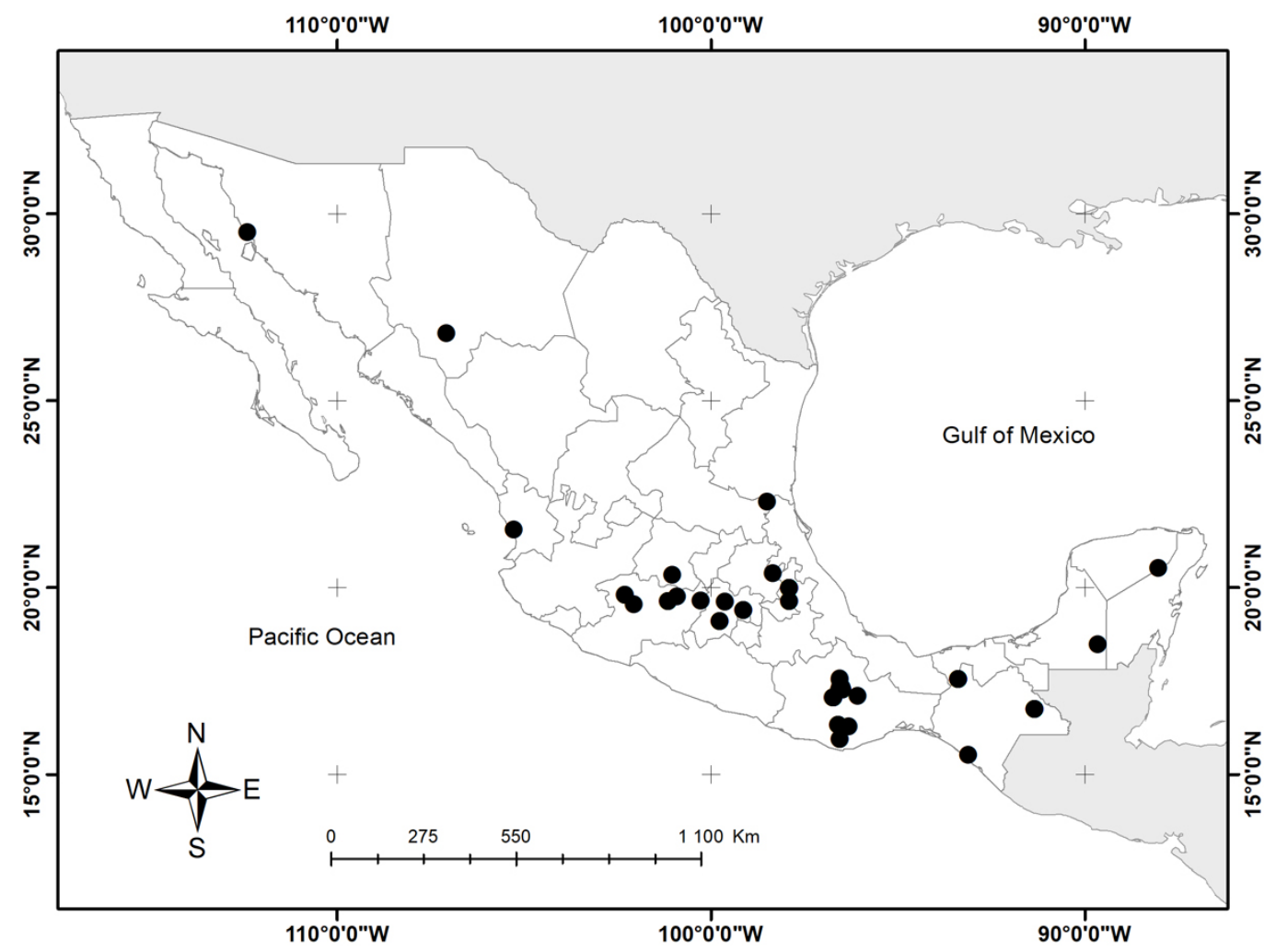

Figure 1. Map of reports of useful bryophytes with associated TEK in different states of Mexico (black circles). 

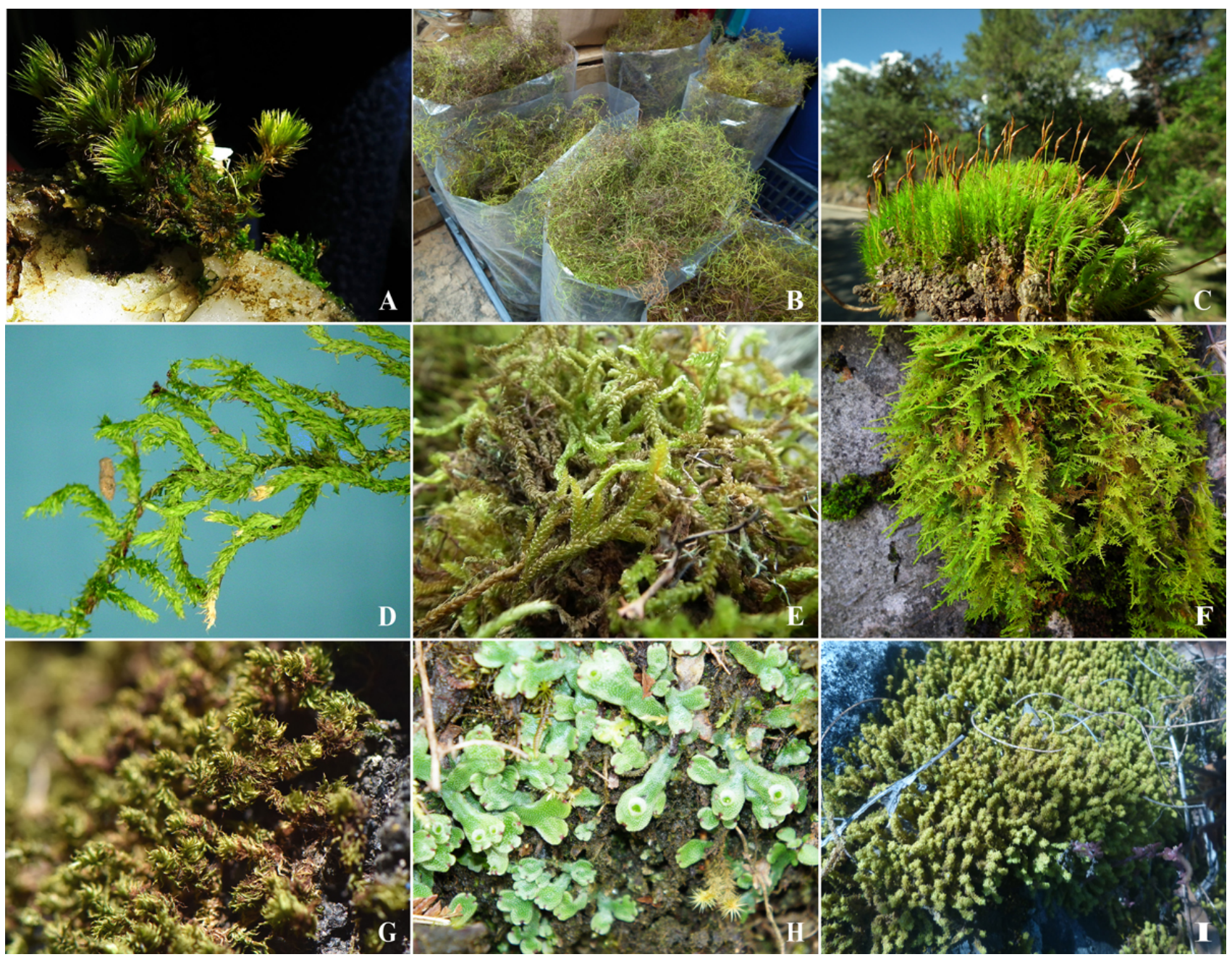

Figure 2. Some bryophytes species used in México with ceremonial (A. Campylopus sp., B. Dendropogonella rufescens, C. Dicranum sp., D. Meteorium sp., E. Pilotrichella flexilis, F. Thuidium delicatulum), craft (G. Bryum sp.), and medicinal (H. Marchantia sp., I. Pleurochaete squarrosa) proposes.

variations. The most evident cases of linguistic variations occur in Nahuatl, the language with the highest extant speaker number, and with the most variants in the country (Moseley 2007). Zapotec in Oaxaca state also has name variations, where the terms to describe mosses are different even between localities in the same region (Ruegsegger \& Ruegsegger 1955, Luna-José \& Rendón-Aguilar 2012).

Traditional moss uses related to Christmas or as decorative material are the most common. These results are in contrast with the worldwide trend of medicinal use that includes few records in Mexico (Alcorn 1984, Delgadillo 2000, Harris 2008, López-Santiago 2015, Glime 2017b). Using mosses to decorate Nativity scenes resulted from a Christmas tradition that began in the nineteenth century and has continued until today (Anastacio-Martínez et al. 2017b). Due to the large volumes harvested for this purpose, this represents a threat to bryophyte (moss) diversity and individual populations. On a national scale, the annual harvest can exceed 900 tons (Zamora-Martínez et al. 2008). Gómez-Peralta \& Wolf (2001) documented the harvest of approximately 50 tons of bryophytes in the Monarch Butterfly Reserve in Michoacán state. Accordingly, 14 species were recorded for Christmas use in Mexico, and there may be more. However, this is not the only religious activity in which bryophytes are used. Other examples are the Patamban flower carpets in Michoacán state, as well as rituals in Zapotec communities in the northern Oaxaca state (Martínez-López et al. 2015, 2017, Cornejo-Tenorio \& Ibarra-Manríquez 2019). For handicrafts, records of bryophytes included a dubious report on the manufacture of codex paper -making in ancient Mexico, and as filling material to lighten heavy loads by Tzeltales in Chiapas state (Berlin et al. 1974, Bay \& Linares 2016). 
Table 1. Traditional knowledge records that do not specify moss taxa. Information includes locality, native name (with the native language name), associated TEK description, and source. Use categories are represented by CE: Ceremonial, CR: Craft, EN: Environmental and ME: Medicinal.

\begin{tabular}{|c|c|c|c|c|}
\hline Locality & $\begin{array}{l}\text { Native } \\
\text { name }\end{array}$ & \multicolumn{2}{|c|}{ Use category and description } & Reference \\
\hline Center of Mexico & $\begin{array}{l}\text { Tepitoton } \\
\text { teamoxtli, } \\
\text { Náhuatl }\end{array}$ & \multicolumn{2}{|c|}{ ME: Treatment of various illnesses by the Aztecs. } & $\underline{\text { De la Cruz (1552) }}$ \\
\hline Mexico City & & \multicolumn{2}{|c|}{$\begin{array}{l}\text { CE: Used as decoration material to make the nativity scenes in post-independent } \\
\text { Mexico. }\end{array}$} & $\frac{\text { Calderón de la Barca }}{\underline{(1843)}}$ \\
\hline Center of Mexico & $\begin{array}{l}\text { Amoxtli, } \\
\text { Náhuatl. }\end{array}$ & \multicolumn{2}{|c|}{$\begin{array}{l}\text { CR: An aquatic moss (of unknown source) was used to make codices in pre- } \\
\text { Hispanic times. This report is dubious and could include other organisms like } \\
\text { algae. }\end{array}$} & $\frac{\text { Bay \& Linares }}{\underline{(2016)}}$ \\
\hline $\begin{array}{l}\text { San Pedrito (Otomi- } \\
\text { Tepegua ethnicity), } \\
\text { Hidalgo. }\end{array}$ & & \multicolumn{2}{|c|}{$\begin{array}{l}\text { EN: Women of the community observed reduction in the availability of mosses in } \\
\text { the forest. They record this knowledge because they are the group in charge of } \\
\text { the use and management of the non-wood forest products. }\end{array}$} & $\frac{\text { Vázquez-García }}{\underline{(2015)}}$ \\
\hline $\begin{array}{l}\text { Las Brisas, Barra } \\
\text { de Cahoacán, } \\
\text { Chiapas. }\end{array}$ & & \multicolumn{2}{|c|}{$\begin{array}{l}\text { EN: Mosses growing on bamboo (Otatea acuminata (Munro) C.E. Calderón \& } \\
\text { Soderstr.) are used as indicators of its maturity. This criterium is to choose those } \\
\text { stems useful in the construction of rural housing. }\end{array}$} & $\frac{\text { Moreno-Martínez et }}{\underline{\text { al. }(2012)}}$ \\
\hline $\begin{array}{l}\text { North of Michocán } \\
\text { state. }\end{array}$ & & \multicolumn{2}{|c|}{$\begin{array}{l}\text { EN: The presence of mosses is considered essential for the establishment of } \\
\text { agave plantlets (Agave inaequidens } \mathrm{K} \text {. Koch) because it is related to adequate } \\
\text { moisture conditions. This agave species is important in the local production of } \\
\text { mezcal. }\end{array}$} & Torres et al. (2015) \\
\hline $\begin{array}{l}\text { Moss genera use } \\
\text { (e.g., Dicranum, Hyt } \\
\text { have intense colors, } \\
\text { growth forms (Anast } \\
\text { Tenorio \& Ibarra-N } \\
\text { important for the } \\
\text { conservation activiti } \\
\text { 1956). In the Ixtlán } \\
\text { these plants are part } \\
\text { areas, an importar } \\
\text { population (Fuente- } \\
\text { Bryophytes are the }\end{array}$ & $\begin{array}{l}\text { for cerer } \\
\text { num, Polyt } \\
\text { large size } \\
\text { acio-Martír } \\
\text { anríquez } \\
\text { developr } \\
\text { es of bryor } \\
\text { de Juárez c } \\
\text { of the crite } \\
t \text { econom } \\
\text { Carrasco } \\
\text { visual attro }\end{array}$ & $\begin{array}{l}\text { honial and crafts purposes } \\
\text { richum, Thuidium) typically } \\
\text { abundance, and attractive } \\
\text { ez et al. 2017a, b, Cornejo- } \\
019 \text { ). These traits can be } \\
\text { hent of productive and } \\
\text { hytes (Grout 1934, Thieret } \\
\text { ommunity, in Oaxaca state, } \\
\text { ria to designate ecotourism } \\
\text { c activity for the local } \\
\& \text { Ramos-Morales 2013). } \\
\text { ction of trails for visitors, }\end{array}$ & \multicolumn{2}{|c|}{$\begin{array}{l}\text { where they form a large part of the plant biomass; this use } \\
\text { promotes their conservation (pers. obs.). Thus, while some } \\
\text { traditional practices represent a risk, others have positive } \\
\text { effect on bryophyte conservation. Nevertheless, bryophytes } \\
\text { used for medicinal and environmental purposes do not } \\
\text { necessarily have aesthetic characteristics, suggesting an in- } \\
\text { depth traditional knowledge of some of their phytochemical } \\
\text { properties and ecological features. Some examples are the } \\
\text { use of Sematophyllum adnatum to prepare medicinal teas in } \\
\text { Yucatán (Glime 2017b), and small bryophyte species } \\
\text { growing on the bamboo stem to estimate its maturity in } \\
\text { Barra de Cahoacán, Chiapas (Moreno-Martínez et al. 2012). }\end{array}$} \\
\hline
\end{tabular}

Table 2. Terms for "moss" in some native languages in Mexico.

\begin{tabular}{lccc}
\hline Native term & Language & Locality & Source \\
\hline Con & Tzeltal & Chiapas state & $\underline{\text { Berlin et al. (1974) }}$ \\
Tecata & Spanish & Capécuaro, Michoacán & $\underline{\text { Delgadillo (2000) }}$ \\
Tsot-zé & Tzeltal & Lacanjá and laguna El Suspiro, Chiapas & $\underline{\text { Delgadillo (2000) }}$ \\
Tsa'nk & Mixe & Santa María Tlahuitoltepec, Oaxaca & $\underline{\text { Gallardo-Jiménez (2013) }}$ \\
Xibeu' $_{\text {' }}$ & Zapotec & Miahuatlán District, Oaxaca & $\underline{\text { Ruegsegger \& Ruegsegger (1955) }}$ \\
Mbaxhs * $_{\text {Yamasa * }}^{\text {Zapotec }}$ & Seri & Buenavista Loxicha, Oaxaca & $\underline{\text { Luna-José \& Rendón-Aguilar (2012) }}$ \\
\hline
\end{tabular}

* According to the source, the term also applies to liverworts and lichens. 
Ethnobotany of bryophytes in Mexico

Table 3. Terms in native languages in Mexico to classify mosses according to the substrates where they grow.

\begin{tabular}{|c|c|c|c|c|}
\hline \multirow[b]{2}{*}{ Substrate } & \multicolumn{4}{|c|}{ Native languages, localities, and source } \\
\hline & $\begin{array}{c}\text { Tzeltal, Chiapas }(\text { Berlin et } \\
\underline{\text { al. 1974) }}\end{array}$ & $\begin{array}{l}\text { Náhuatl, Mexico (De la } \\
\text { Cruz 1552) }\end{array}$ & $\begin{array}{l}\text { Mayan, Lacanjá and laguna El Suspiro, } \\
\text { Chiapas (Delgadillo 2000) }\end{array}$ & $\begin{array}{c}\text { Zapotec, San Agustín } \\
\text { Loxicha, Oaxaca (Luna-José } \\
\text { \& Rendón-Aguilar 2012) }\end{array}$ \\
\hline Trees & Con te $?=$ Tree moss & & $\begin{array}{c}\text { Much-I-ché }=\text { Attached to trees } \\
\text { Ushushem-ché }=\text { Living attached to trees }\end{array}$ & \\
\hline Rocks & & $\begin{array}{l}\text { Teamoxtli }=\text { Rock- } \\
\text { inhabiting moss }\end{array}$ & Kushem-tunich $=$ Attached to a rock & \\
\hline Soil & $\begin{array}{c}\text { Con lumilal }=\text { Ground } \\
\text { moss }\end{array}$ & & & $\begin{array}{c}\text { Mbaxs lad ble }=\text { Growing on } \\
\text { the ground }\end{array}$ \\
\hline
\end{tabular}

De la Cruz's (1552) work can be considered as the oldest record of medicinal use of bryophytes in Mexico. However, there is a knowledge gap until new medicinal reports appeared in recent decades (Alcorn 1984, Delgadillo 2000, López-Santiago 2015, Glime 2017a). Bryophytes have a wide variety of secondary metabolites and they are used for antibiotics and pharmaceutical production (Pandey \& Alam 2020). In Mexico, plants reported with antibacterial activity used in traditional medicine do not include bryophytes (Sharma et al. 2017). Therefore, the species presented in this review point to the necessity of such studies.

Regarding environmental uses, Torres et al. (2015) show that mosses are considered a suitable substrate for germination and seed development by farmers, of such species as Agave inaequidens K. Koch in Michoacán state. The capacity of bryophyte layers to promote seed germination has been previously reported; they reduce the risk of predation and maintain stable conditions of temperature and humidity necessary for their development (Tooren 1988, Soudzilovskaia et al. 2011). Another example of environmental use is cited by Jasso-Arriaga et al. (2016), where people conserve mosses layers in the forest floor to maintain the harvest of wild mushrooms in the state of Mexico. Other reports provide information on changes in bryophyte diversity in some regions of Mexico. For example, Vázquez-García (2015) shows that women in the community of San Pedrito, Hidalgo, observed a reduction in moss populations in the forest over time. Although it is not clear if the women knew the importance and roles of bryophytes in the forest, this information is a reference to possible effects of habitat degradation and climate change on a local scale (Wolverton et al. 2014). The environmental uses of bryophytes are among the rarest worldwide. Therefore, these represent an important antecedent of traditional ecological knowledge of bryophytes in Mexico thus far overlooked.

Mexico has an extensive heritage of useful plants, and bryophytes are part of this biocultural wealth. The information on the uses and traditional knowledge of bryophytes may increase with their inclusion in ethnobotanical works. It is not clear why bryophytes are not considered in these studies. Some reasons may include, for example, the assumption that bryophytes used in different parts of Mexico are the same species, the development of research limited to vascular flora, and the low value given by researchers to the identity of bryophyte species and their TEK (Kimmerer 2003). Collaboration between bryologists, ethnobiologists, and local people can improve this situation and avoid the risk of losing valuable information, especially when languages and traditional knowledge are at risk of disappearing (Moseley 2007, Campbell \& Belew 2018).

This work provides a first list of the bryophyte's species used in Mexico, as well as associated TEK. Thus, this study updates the information of useful bryophyte species in the country and highlights the ethnobotanical knowledge of a group of neglected plants.

\section{Acknowledgments}

Authors thank L. Cortés Zárraga, M. Gómez Peralta and M. D. Luna-Krauletz for sharing information on useful bryophyte records in Mexico. Also, to J. López-Santiago and J. A. Cruz López for sharing bryophyte pictures. We appreciate valuable comments of I. Santiago Bedolla, D. Escolástico Ortíz, Corrige-moi group, and the Laboratory of Bryology of the Université du Québec en AbitibiTémiscamingue in the development of the document. Finally, we thank two anonymous reviewers and the associate editor for comments to improve the document.

\section{Literature cited}

Alam A. 2016. Ethnobryology of India. In: Pullaiah T, Krishnamurthy KV, Bahadur B, eds. Ethnobotany of India, V. 2, Western Ghats and West Coast of Peninsular India. New Jersey, USA: Apple Academis Press, pp. 313-329. ISBN: 978-1-77188-404-4 
Alcorn JB. 1984. Huastec Mayan Ethnobotany. Texas, USA: University Texas Press. ISBN 13: 9780292715431

Anastacio-Martínez ND, Franco-Maass S, ValtierraPacheco E, Nava-Bernal G. 2017a. Aprovechamiento de productos forestales no maderables en los bosques de montaña alta, centro de México. Revista Mexicana de Ciencias Forestales 7: 21-38. DOI: https://doi.org/ $\underline{10.29298 / \text { rmcf.v7i37.49 }}$

Anastacio-Martínez ND, Franco-Maass S, ValtierraPacheco E, Nava-Bernal G. 2017b. El proceso de extracción y comercialización del musgo (Thuidium delicatulum) en el Estado de México. CIENCIA ergosum 24: 44-53. DOI: https://doi.org/10.30878/ces.v24n1 $\underline{\mathrm{a} 5}$

Bay R, Linares E. 2016. Ethnobotany and Ethnohistorical Sources of Mesoamerica. In: Lira R, Casas A, Blancas J, eds. Ethnobotany of Mexico: Interactions of People and Plants in Mesoamerica. New York, EUA: Springer, pp. 41-65. ISBN: 978-1-4614-6668-0

Berkes F. 1993. Traditional ecological knowledge in perspective. In: Inglis JT, ed. Traditional Ecological Knowledge: Concepts and Cases. Ottawa, Canada: Canadian Museum of Nature and the International Development Research Centre; p. 1-9. ISBN: 978-0889366831

Berkes F. 1999. Sacred Ecology. Philadelphia, USA: Taylor \& Francis. ISBN: 978-0415958295

Berkes F, Colding J, Folke C. 2000. Rediscovery of traditional ecological knowledge as adaptive management. Ecological Applications 10: 1251-1262. DOI: https://doi.org/10.1890/1051-0761(2000)010[1251: roteka]2.0.co;2

Berlin B, Breedlove D, Raven P. 1974. Principles of Tzeltal plant classification: An Introduction to the Botanical Ethnography of a Mayan-Speaking People of Highland Chiapas. New York, USA: Academic Press. ISBN: 978-0-12-785047-4

Bernal-Ramírez LA, Bravo-Avilez D, Fonseca-Juárez RM, Yáñez-Espinosa L, Gernandt DS, Rendón-Aguilar B. 2019. Usos y conocimiento tradicional de las gimnospermas en el noreste de Oaxaca, México. Acta Botanica Mexicana 126: 1-24. DOI: https://doi.org/10. $\underline{21829 / \mathrm{abm} 126.2019 .1471}$

Brush S. 1993. Indigenous knowledge of biological resources and intellectual property rights: The role of anthropology. American Anthropologist 95: 653-671. DOI: $\underline{\text { https://doi.org/10.1525/aa.1993.95.3.02a00060 }}$

Caballero J, Cortés L. 1982-2020. Base de Datos Etnobotánicos de Plantas de México (BADEPLAM). Ciudad de México, México: Jardín Botánico, Instituto de Biología, Universidad Nacional Autónoma de México.

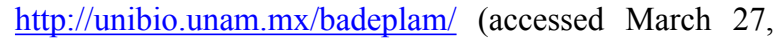
2020)
Calderón de la Barca M. 1843. Life in Mexico during a residence of two years in that country. Boston, USA: Chapman and Hall.

Campbell L, Belew A. 2018. Cataloguing the World's Endangered Languages. New York, USA: Routledge. ISBN: 9781138922082

Campos-Villanueva A, Cortés-Arriaga L, Dávila-Aranda P, García-Mendoza A, Reyes-Santiago J, Toris-Acosta G, Torres-Colín L, Torres-Colín R. 1992. Plantas y Flores de Oaxaca. Instituto de Biología, Universidad Nacional Autónoma de México. ISBN: 9683627226

CBD [Convenio sobre la Diversidad Biológica]. 2020. Convenio sobre la Diversidad Biológica. Montreal, Canada: Convenio sobre la Diversidad Biológica. https:// www.cbd.int/undb/media/factsheets/undb-factsheets-esweb.pdf (accessed June 13, 2020).

Cornejo-Tenorio G, Ibarra-Manríquez G. 2019. Los tapetes florales de Patamban, Michoacán, México: elaboración y especies utilizadas. Revista Mexicana de Biodiversidad 90: 1-19. DOI: https://doi.org/10.22201/ib.20078706e. 2019.90.2700

De la Cruz M. 1552. Libellus de Medicinalibus Indorum Herbis, Latin traslation by Juan Badiano. México DF, México: Instituto Mexicano del Seguro Social.

Delgadillo MC. 2000. Native moss names in Mexico. Evansia 17: 84-86.

Delgadillo MC. 2010. LATMOSS. $\underline{\text { http:// }}$ www.ibiologia.unam.mx/briologia/www/index/Bases.ht $\underline{\mathrm{ml}}$ (accessed March 15, 2020)

Delgadillo MC. 2014. Biodiversidad de Bryophyta (musgos) en México. Revista Mexicana de Biodiversidad 85: 100-105. DOI: https://doi.org/10.7550/rmb.30953

Delgadillo MC, Cárdenas MA. 1990. Manual de briofitas. México DF, México: Universidad Nacional Autónoma de México. ISBN: 9789683616319

Delgadillo MC, Juárez-Martínez C. 2014. Biodiversidad de Anthocerotophyta y Marchantiophyta en México. Revista Mexicana de Biodiversidad 85: 106-109. DOI: https:// doi.org/10.7550/rmb.30954

Ellis LT, Wilbraham J, Aleffi M, Asthana AK, Rawat KK, Gupta D, Sahu V, Katiyar P, Asthana G, Srivastava A, Baráth K, Bednarek-Ochyra H, Bruno Silva J, Emanuely de Araújo Farias C, Rangel Germano S, Czernyadjeva IV, Doroshina GYa, Delgadillo MC, Peña Retes P, Erzberger P, Fuertes E, Garcia-Avila D, Garilleti R, Hedderson TA, West A, Hugonnot V, Kürschner $H$, Lagrandie J, Lara F, Draper I, Lebouvier M, Lönnell N, Hallingbäck T, Mesterházy A, Muñoz J, Németh CS, Park SJ, Sun B-Y, Pérez G, Plášek V, Poponessi S, Vernanzoni R, Gigante D, Philippe M, Porley RD, Sérgio C, Ministro P, Ştefănuţ S, Suárez GM, Flores JR, Sulayman M, Wilding N, Yoon Y-J. 2018. New national and regional bryophyte records, 54. Journal of Bryology 
40: 74-97. DOI: https://doi.org/10.1080/03736687.2018. $\underline{1425573}$

Escolástico-Ortíz DA, Juárez-Martínez C. 2018. Notothylas javanica (Anthocerotophyta: Notothyladaceae): nuevo registro para la brioflora de México. Acta Botanica Mexicana 123: 183-190. DOI: https://doi.org/10.21829/ abm123.2018.1287

Felger RS, Moser MB. 1985. People of the desert and sea: Ethnobotany of the Seri Indians. Arizona, USA: University of Arizona Press. ISBN: 9780816512676

Flowers S. 1957. Ethnobryology of the Gosuite Indians of Utah. The Bryologist 60: 11-14. DOI: https://doi.org/ $\underline{10.2307 / 3240044}$

Fuente-Carrasco ME, Ramos-Morales MF. 2013. El ecoturismo comunitario en la Sierra Juárez-Oaxaca, México: entre el patrimonio y la mercancía. Otra Economía 7: 66-79. DOI: https://doi.org/10.4013/otra. $\underline{2013.712 .04}$

Gallardo-Jiménez J. 2013. Plantas medicinales del municipio de Santa María Tlahuiltoltepec, Mixe, Oaxaca. BSc Thesis. Universidad de la Sierra Juárez.

García-Ávila D. 2019. Musgos (Bryophyta). In: CONABIO, ed. La biodiversidad en Michoacán Estudio de caso 2. Ciudad de México, México: Comisión Nacional para el Conocimiento y Uso de la Biodiversidad; p. 175-180. ISBN: 978-607-8570-33-1

Glime J. 2017a. Chapter 7-1, Gardening: Horticultural Uses. In: Glime J, ed. Bryophyte Ecology. Michigan, USA: Michigan Technological University and the International Association of Bryologists; p. 1-30. http:// digitalcommons.mtu.edu/bryophyte-ecology/ (accessed March 23, 2020).

Glime J. 2017b. Chapter 2-1, Medical Uses: Medical Conditions. In: Glime $\mathrm{J}$, ed. Bryophyte Ecology. Michigan, USA: Michigan Technological University and the International Association of Bryologists; p. 1-22. http://digitalcommons.mtu.edu/bryophyte-ecology/ (accessed March 23, 2020).

Goffinet B, Buck W. 2020. Classification of the Bryophyta. http://bryology.uconn.edu/classification/ (accessed Mar 25, 2020).

Gómez-Peralta M, Angón-Torres MP. 2004. Recursos forestales no maderables aprovechados en Morelia. Morelia, Michoacán: Gobierno del Estado de Michoacán, Secretaria de Urbanismo y Medio Ambiente. México. ISBN: 970-703-290-1

Gómez-Peralta M, Wolf JHD. 2001. Commercial bryophyte harvesting in the Monarch Butterfly Biosphere Reserve, Sierra Chincua, Michoacan, Mexico. The Bryologist 104: 517-521. DOI: https://doi.org/10.1639/0007-2745(2001) 104[0517:cbhitm]2.0.co;2

Grout AJ. 1934. Mosses. The Scientific Monthly 38: 270-273.
Harris ESJ. 2008. Ethnobryology: traditional uses and folk classification of bryophytes. The Bryologist 111: 169-217. DOI: https://doi.org/10.1639/0007-2745(2008) 111[169:etuafc]2.0.co;2

Jasso-Arriaga X, Martínez-Campos ÁR, Gheno-Heredia YA, Chávez MC. 2016. Conocimiento tradicional y vulnerabilidad de hongos comestibles en un ejido dentro de un área natural protegida. Polibotánica 42: 167-195. DOI: https://doi.org/10.18387/polibotanica.42.9

Kimmerer RW. 2003. Gathering moss: a natural and cultural history of mosses. Oregon, USA: Oregon State University Press and Corvallis. ISBN: 9780870714993

López-Mendoza LM. 2020. Los huertos familiares del municipio de Santa Catarina Lachatao, Ixtlán, Oaxaca. BSc Thesis. Universidad de la Sierra Juárez.

López-Santiago J. 2015. Plantas útiles del municipio de San Pablo Macuiltianguis, Oaxaca. BSc Thesis. Universidad de la Sierra Juárez.

Luna-José AdL, Rendón-Aguilar B. 2012. Traditional knowledge among Zapotecs of Sierra Madre Del Sur, Oaxaca. Does it represent a base for plant resources management and conservation? Journal of Ethnobiology and Ethnomedicine 8: 1-24. DOI: https://doi.org/10. 1186/1746-4269-8-24

Mapes C, Basurto F. 2016. Biodiversity and edible plants of Mexico. In: Lira R, Casas A, Blancas J, eds. Ethnobotany of Mexico: Interactions of People and Plants in Mesoamerica. New York, EUA: Springer; p. 83-131. ISBN: 978-1-4614-6668-0

Martínez-López J, Martínez y Ojeda E, Blancas-Vázquez JJ, Acosta-Ramos A. 2015. Valor cultural de los recursos forestales no maderables en Capulálpam de Méndez, Oaxaca. Cathedra et Scientia International Journal 1: 81-98.

Martínez-López J, Ramos AA, Martínez y Ojeda E, Manzano-Méndez F. 2017. Recursos forestales no maderables en dos comunidades zapotecas de la Sierra Juárez de Oaxaca. Revista Mexicana de Ciencias Forestales 7: 37-52. DOI: https://doi.org/10.29298/ rmcf.v7i35.73

Mondragón D, Villa-Guzmán DM. 2008. Estudio etnobotánico de las bromelias epifitas en la comunidad de Santa Catarina Ixtepeji, Oaxaca, México. Polibotánica 26: 175-191.

Moreno-Martínez JL, Ruiz-Bello C, Espinosa-Zaragoza S, Macian-Núñez de Castro JM. 2012. El otate (Otatea acuminata) y la palma real (Sabal mexicana): Recursos ancestrales usados en la construcción de vivienda rural. Agro Productividad 5: 26-35.

Moseley C. 2007. Encyclopedia of the world's endangered languages. New York, USA: Routledge. ISBN: 9780700711970 
Pandey S, Alam A. 2020. Bryo-Pharmaceuticals. In: Singh A, Singh P, Bithel N, eds. Advanced Pharmacological Uses of Medicinal Plants and Natural Products. Uttarakhand, India: Gurukul Kangri University; p. 269-284. ISBN: 9781799820949

Rees J. 1976. The Oaxaca Christmas plant market. Journal of the Bromeliad Society 26: 223-232.

Ruegsegger M, Ruegsegger J. 1955. Vocabulario Zapoteco del dialecto de Miahuatlán del estado de Oaxaca. México DF, México: Instituto Lingüístico de Verano, Dirección General de Asuntos Indígenas, Secretaría de Educación Pública.

Sarukhán J, Koleff P, Carabias J, Soberón J, Dirzo R, Llorente-Bousquets J, Halffter G, González R, March I, Mohar A, Anta S, De La Maza J. 2009. Capital Natural de México: Conocimiento actual, Evaluación y Perspectivas de Sustentabilidad. Síntesis. México DF, México: Comisión Nacional para el Conocimiento y Uso de la Biodiversidad. ISBN: 978-607-7607-09-0

Sharma A, Flores-Vallejo RDC, Cardoso-Taketa A, Villarreal ML. 2017. Antibacterial activities of medicinal plants used in Mexican traditional medicine. Journal of Ethnopharmacology 208: 264-329. DOI: https://doi.org/ 10.1016/j.jep.2016.04.045

Söderström L, Hagborg A, von Konrat M, BartholomewBegan S, Bell D, Briscoe L, Brown E, Cargill DC, Costa DP, Crandall-Stotler BJ, Cooper ED, Dauphin G, Engel JJ, Feldberg K, Glenny D, Gradstein SR, He X, Heinrichs J, Hentschel J, Ilkiu-Borges AL, Katagiri T, Konstantinova NA, Larraín J, Long DG, Nebel M, Pócs T, Puche F, Reiner-Drehwald E, Renner MAM, SassGyarmati A, Schäfer-Verwimp A, Segarra-Moragues JG, Stotler RE, Sukkharak P, Thiers BM, Uribe J, Váňa J, Villarreal JC, Wigginton M, Zhang L, Zhu RL. 2016. World checklist of hornworts and liverworts. PhytoKeys 59: 1-828. DOI: https://doi.org/10.3897/phytokeys.59. $\underline{6261}$

Soudzilovskaia NA, Graae BJ, Douma JC, Grau O, Milbau A, Shevtsova A, Wolters L, Cornelissen JH. 2011. How do bryophytes govern generative recruitment of vascular plants? The New Phytologist 190: 1019-1031. DOI: https://doi.org/10.1111/j.1469-8137.2011.03644.x

Thieret JW. 1956. Bryophytes as economic plants. Economic Botany 10: 75-91. DOI: https://doi.org/10. $\underline{1007 / b f 02985319}$

Associate editor: Arturo de Nova

Author contributions: EHR conceived the study, and the review. EHR and CDM wrote the document.
Toledo VM. 1990. La perspectiva etnoecológica: cinco reflexiones acerca de las "ciencias campesinas" sobre la naturaleza con especial referencia a México. Ciencias 4: 22-29.

Toledo VM, Barrera-Bassols N, Boege E. 2019. ¿Qué es la diversidad biocultural? Michoacán, México: Universidad Nacional Autónoma de México, Red para el Patrimonio Biocultural, Consejo Nacional de Ciencia y Tecnología. https://patrimoniobiocultural.com/producto/ que-es-la-div ersidad-biocultural// (accessed March 23, 2020)

Tooren BF. 1988. The fate of seeds after dispersal in chalk grassland: The role of the bryophyte layer. Oikos 53: 41-48. DOI: https://doi.org/10.2307/3565661

Torres I, Blancas J, León A, Casas A. 2015. TEK, local perceptions of risk, and diversity of management practices of Agave inaequidens in Michoacan, Mexico. Journal of Ethnobiology and Ethnomedicine 11: 1-20. DOI: https://doi.org/10.1186/s13002-015-0043-1

Vázquez-García V. 2015. Manejo forestal comunitario, gobernanza y género en Hidalgo, México. Revista Mexicana de Sociología 77: 611-635.

Wolverton S, Chambers KJ, Veteto JR. 2014. Climate Change and Ethnobiology. Journal of Ethnobiology. 34: 273-275. DOI: https://doi.org/10.2993/0278-0771-34.3. $\underline{273}$

Zamora-Martínez MC, Velasco-Bautista E, Arellano-Rivas A. 2008. Manual que establece los Criterios Técnicos para el Aprovechamiento Sustentable de Recursos Forestales no Maderables de Clima Templado-Frío. México DF, México: Subsecretaria de Fomento y Normatividad Ambiental-Dirección General del Sector Primario y Recursos Naturales Renovables-Secretaria de Medio Ambiente y Recursos Naturales. http:// centro.paot.org.mx/documentos/semarnat/Manual_Clima Templado.pdf (accessed March 28, 2020)

Zolla C, Argueta A. 2009. Biblioteca Digital de la Medicina Tradicional Mexicana. México DF, México: Universidad Nacional Autónoma de México, Landsteiner Scientific, Comisión Nacional para el Desarrollo de los Pueblos Indios. http://www.medicinatradicionalmexica na.unam.mx (accessed March 24, 2020) 
Appendix 1. Traditional knowledge of Mexican bryophytes. The table includes division, family, and species. Updated scientific names of species are in square brackets. The records include locality and, in some cases, native name (in italics, and English translation when possible), and name of the native language. The category and description of the associated use of each species are presented when information was available in the original publication. Use categories are represented by CE: Ceremonial, CR: Craft, ME: Medicinal, and OR: Ornamental.

\begin{tabular}{|c|c|c|c|c|}
\hline \multirow[t]{2}{*}{ Division, family, and species } & \multicolumn{4}{|c|}{ Description of the associated traditional knowledge } \\
\hline & Locality & Native name & Use category and description & Reference \\
\hline \multicolumn{5}{|l|}{ Marchantiophyta } \\
\hline \multicolumn{5}{|l|}{ Lophocoleaceae } \\
\hline $\begin{array}{l}\text { Chiloscyphus orizabensis } \\
\text { Gottsche }\end{array}$ & Chiapas & $\begin{array}{l}\text { Con } \check{c} \text { ' en (cave moss in } \\
\text { Tzeltal). }\end{array}$ & $\begin{array}{l}\text { CR: Sometimes used as a } \\
\text { filling for bedding or to ease } \\
\text { the weight of backloads. } \\
\text { CE: As ornament for religious } \\
\text { purposes. }\end{array}$ & Berlin et al. (1974) \\
\hline \multicolumn{5}{|l|}{ Marchantiaceae } \\
\hline Marchantia sp. & Northeastern Mexico. & $\begin{array}{l}\text { P-miim ha (water lady } \\
\text { or mother in Huastec } \\
\text { Mayan). }\end{array}$ & $\begin{array}{l}\text { ME: Used in combination with } \\
\text { Begonia L. and Lithachne } \\
\text { pauciflora (Sw.) P. Beauv., for } \\
\text { mouth sores and fever. }\end{array}$ & $\underline{\text { Alcorn }(1984)}$ \\
\hline \multicolumn{5}{|l|}{ Zoopsidoideae } \\
\hline $\begin{array}{l}\text { Lepidozia muenchiana } \\
\text { Steph }\end{array}$ & Chiapas state. & $\begin{array}{l}\text { Con č' en (cave moss in } \\
\text { Tzeltal). }\end{array}$ & $\begin{array}{l}\text { CR: Same uses as Chiloscyphus } \\
\text { orizabensis. }\end{array}$ & Berlin et al. (1974) \\
\hline \multicolumn{5}{|l|}{ Bryophyta } \\
\hline \multicolumn{5}{|l|}{ Anomodontaceae } \\
\hline $\begin{array}{l}\text { Herpetineuron toccoae } \\
\text { (Sull. \& Lesq.) Cardot }\end{array}$ & Tlayehualancingo, Puebla. & $\begin{array}{l}\text { Shakuwaki (moss in } \\
\text { Totonac) }\end{array}$ & & $\underline{\text { Delgadillo (2000) }}$ \\
\hline \multicolumn{5}{|l|}{ Brachytheciaceae } \\
\hline $\begin{array}{l}\text { Brachythecium } \\
\text { plumosum (Hedw.) } \\
\text { Schimp. }\end{array}$ & $\begin{array}{l}\text { San Francisco } \\
\text { Ixquihuacán, Puebla. }\end{array}$ & $\begin{array}{l}\text { Tipach (rock hair in } \\
\text { Náhuatl). }\end{array}$ & & Delgadillo (2000) \\
\hline Squamidium sp. & $\begin{array}{l}\text { Santa Catarina Ixtepeji, } \\
\text { Oaxaca. }\end{array}$ & $\begin{array}{l}\text { Musgo de encino } \\
\text { (oakmoss in Spanish). }\end{array}$ & $\begin{array}{l}\text { CE: Harvested in the forest and } \\
\text { sold in the Christmas period. }\end{array}$ & $\frac{\text { Mondragón \& }}{\text { Villa-Guzmán }}$ \\
\hline \multicolumn{5}{|l|}{ Bryaceae } \\
\hline \multirow[t]{2}{*}{ Bryum spp. } & Chiapas state. & $\begin{array}{l}\text { Con č' en (cave moss in } \\
\text { Tzeltal). }\end{array}$ & $\begin{array}{l}\text { CR: Same uses as Chiloscyphus } \\
\text { orizabensis and Lepidozia } \\
\text { muenchiana }\end{array}$ & Berlin et al. (1974) \\
\hline & $\begin{array}{l}\text { Patamban, Tangancícuaro, } \\
\text { Michoacán. }\end{array}$ & $\begin{array}{l}\text { Flor de Piedra (Stone } \\
\text { flower in Spanish). }\end{array}$ & $\begin{array}{l}\text { CE: Used with other } 148 \text { species of } \\
\text { vascular plants, to make the } \\
\text { "Patamban flower carpets". This } \\
\text { activity is related to the Cristo Rey } \\
\text { religious ceremony in October. The } \\
\text { bryophyte is chosen for its useful } \\
\text { green color to decorate the carpets, } \\
\text { and it is harvested from pine-oak } \\
\text { forests. }\end{array}$ & $\begin{array}{l}\text { Cornejo-Tenorio \& } \\
\underline{\text { Ibarra-Manríquez }} \\
\underline{(2019)}\end{array}$ \\
\hline
\end{tabular}




\begin{tabular}{|c|c|c|c|c|}
\hline \multirow[t]{2}{*}{ Division, family, and species } & \multicolumn{4}{|c|}{ Description of the associated traditional knowledge } \\
\hline & Locality & Native name & Use category and description & Reference \\
\hline $\begin{array}{l}\text { Brachymenium } \\
\text { spirifolium (Müll. Hal.) } \\
\text { A. Jaeger }\end{array}$ & $\begin{array}{l}\text { San Francisco } \\
\text { Ixquihuacán, Puebla. }\end{array}$ & $\begin{array}{l}\text { Ipachllolima (lime hair } \\
\text { in Náhuatl). }\end{array}$ & & $\underline{\text { Delgadillo (2000) }}$ \\
\hline Bryum argenteum Hedw. & $\begin{array}{l}\text { San Francisco } \\
\text { Ixquihuacán, Puebla. }\end{array}$ & $\begin{array}{l}\text { Tipach (rock hair in } \\
\text { Náhuatl). }\end{array}$ & & $\underline{\text { Delgadillo (2000) }}$ \\
\hline $\begin{array}{l}\text { Bryum procerum } \\
\text { Schimp. ex Besch. }\end{array}$ & $\begin{array}{l}\text { Jesús del Monte and San } \\
\text { Miguel del Monte, } \\
\text { Michoacán. }\end{array}$ & $\begin{array}{l}\text { Musgo or gusano (moss } \\
\text { or worm in Spanish). }\end{array}$ & $\begin{array}{l}\text { CE: Used for Christmas nativity } \\
\text { scenes }\end{array}$ & $\begin{array}{l}\text { Gómez-Peralta \& } \\
\underline{\text { Angón-Torres }} \\
\underline{(2004)}\end{array}$ \\
\hline \multicolumn{5}{|l|}{ Cryphaceae } \\
\hline $\begin{array}{l}\text { Cryphaea patens } \\
\text { Hornsch. ex Müll. Hal. }\end{array}$ & $\begin{array}{l}\text { San Francisco } \\
\text { Ixquihuacán, Puebla. }\end{array}$ & $\begin{array}{l}\text { Limpach (lime hair in } \\
\text { Náhuatl). }\end{array}$ & & $\underline{\text { Delgadillo (2000) }}$ \\
\hline \multirow[t]{4}{*}{$\begin{array}{l}\text { Dendropogonella } \\
\text { rufescens (Schimp.) E. } \\
\text { Britton }\end{array}$} & Oaxaca City, Oaxaca. & & $\begin{array}{l}\text { CE: It is sold, with other vascular } \\
\text { plants and lichens, at the Christmas } \\
\text { market in the Oaxaca city. }\end{array}$ & $\underline{\text { Rees (1976) }}$ \\
\hline & & & $\begin{array}{l}\text { OR: To decorate tables for } \\
\text { handicrafts made with radishes } \\
\text { (Raphanus sativus L.) in the } \\
\text { celebration "Night of radishes" } \\
\text { every December } 23 \text {. }\end{array}$ & $\begin{array}{l}\text { Pers. obs. (E } \\
\text { Hernández- } \\
\text { Rodríguez } 116 \text {, } \\
\text { MEXU) }\end{array}$ \\
\hline & Ixtlán de Juárez, Oaxaca. & & $\begin{array}{l}\text { CE: For the elaboration of an arch } \\
\text { for the celebration of the "Virgen } \\
\text { de la Soledad", a local religious } \\
\text { ceremony held on December } 18 . \\
\text { Also, to decorate the main entrance } \\
\text { of the community and the church } \\
\text { of "Santo Tomás Apóstol" every } \\
\text { December } 21 .\end{array}$ & $\begin{array}{l}\text { Pers. obs. (E } \\
\text { Hernández- } \\
\text { Rodríguez } 408, \\
\text { MEXU) }\end{array}$ \\
\hline & $\begin{array}{l}\text { Santiago Comaltepec, } \\
\text { Oaxaca. }\end{array}$ & & $\begin{array}{l}\text { CE: To decorate arches placed at } \\
\text { the entrance of the community } \\
\text { church on the celebration of } \\
\text { "Santiago Apóstol" in July. }\end{array}$ & $\begin{array}{l}\text { Pers. obs. (E } \\
\text { Hernández- } \\
\text { Rodríguez 116, } \\
\text { MEXU) }\end{array}$ \\
\hline $\begin{array}{l}\text { Sphaerotheciella pinnata } \\
\text { (Schimp.) Manuel }\end{array}$ & $\begin{array}{l}\text { San Francisco } \\
\text { Ixquihuacán, Puebla. }\end{array}$ & $\begin{array}{l}\text { Bopash (trees hair in } \\
\text { Náhuatl). }\end{array}$ & & Delgadillo (2000) \\
\hline \multicolumn{5}{|l|}{ Dicranaceae } \\
\hline \multirow[t]{3}{*}{ Dicranum spp. } & Oaxaca state. & $\begin{array}{l}\text { Lama verde (green } \\
\text { sheet in Spanish). }\end{array}$ & $\begin{array}{l}\text { CE: To make Christmas nativity } \\
\text { scenes. }\end{array}$ & $\begin{array}{l}\text { Campos-Villanueva } \\
\text { et al. }(1992)\end{array}$ \\
\hline & $\begin{array}{l}\text { Santa Catarina Lachatao, } \\
\text { Oaxaca. }\end{array}$ & $\begin{array}{l}\text { Musgo (Moss in } \\
\text { Spanish). }\end{array}$ & $\begin{array}{l}\text { OR: Used as a decorative plant in } \\
\text { home gardens. }\end{array}$ & $\begin{array}{l}\text { López-Mendoza } \\
\underline{(2020)}\end{array}$ \\
\hline & Oaxaca City, Oaxaca. & & $\begin{array}{l}\text { CE: It is sold, with other vascular } \\
\text { plants and lichens, at the Christmas } \\
\text { market in the Oaxaca city. }\end{array}$ & $\underline{\operatorname{Rees}(1976)}$ \\
\hline
\end{tabular}

\section{Entodontaceae}

Entodon beyrichii

(Schwägr.) Müll. Hal.
Tlayehualancingo, Puebla. Shakuwaki (moss in

Totonaco). 


\begin{tabular}{|c|c|c|c|c|}
\hline \multirow[t]{2}{*}{ Division, family, and species } & \multicolumn{4}{|c|}{ Description of the associated traditional knowledge } \\
\hline & Locality & Native name & Use category and description & Reference \\
\hline & $\begin{array}{l}\text { San Francisco } \\
\text { Ixquihuacán, Puebla. }\end{array}$ & $\begin{array}{l}\text { Tizonpach (rock hair in } \\
\text { Náhuatl). }\end{array}$ & & Delgadillo (2000) \\
\hline \multicolumn{5}{|l|}{ Hedwigiaceae } \\
\hline \multirow[t]{2}{*}{$\begin{array}{l}\text { Braunia secunda (Hook.) } \\
\text { Bruch \& Schimp. }\end{array}$} & $\begin{array}{l}\text { Guachochic, Norte de } \\
\text { Humira and Tejaban, Sur } \\
\text { de Cusarare, Chihuahua. }\end{array}$ & $\begin{array}{l}\text { Ré eke bowara, (rock } \\
\text { mustache in } \\
\text { Tarahumara). }\end{array}$ & $\begin{array}{l}\text { ME: It is boiled in water, then used } \\
\text { as a wash for the head to relieve } \\
\text { headache. }\end{array}$ & Delgadillo (2000) \\
\hline & $\begin{array}{l}\text { San Juan Mixtepec, } \\
\text { Oaxaca. }\end{array}$ & $\begin{array}{l}\text { Bzhàazh-nguiè (in } \\
\text { Zapotec, no English } \\
\text { translation available). }\end{array}$ & & Delgadillo (2000) \\
\hline Braunia sp. & $\begin{array}{l}\text { Jesús del Monte and San } \\
\text { Miguel del Monte, } \\
\text { Michoacán. }\end{array}$ & $\begin{array}{l}\text { Musgo or cáscara } \\
\text { (moss or husk in } \\
\text { Spanish). }\end{array}$ & $\begin{array}{l}\text { CE: Harvested and sold for the } \\
\text { elaboration of Christmas nativity } \\
\text { scenes }\end{array}$ & $\begin{array}{l}\text { Gómez-Peralta \& } \\
\underline{\text { Angón-Torres }} \\
\underline{(2004)}\end{array}$ \\
\hline \multicolumn{5}{|l|}{ Hypnaceae } \\
\hline \multirow[t]{4}{*}{$\begin{array}{l}\text { Hypnum amabile (Mitt.) } \\
\text { Hampe }\end{array}$} & Mexico State. & & $\begin{array}{l}\text { CE: Harvested in forests of the } \\
\text { Nevado de Toluca volcano to be } \\
\text { sold during the Christmas period in } \\
\text { Mexico City. }\end{array}$ & $\frac{\text { García-Ávila }}{(2019)}$ \\
\hline & $\begin{array}{l}\text { Monarch Butterfly } \\
\text { Biosphere Reserve, } \\
\text { Michoacán. }\end{array}$ & & $\begin{array}{l}\text { CE: Harvested to be sold in } \\
\text { Mexico City. }\end{array}$ & $\begin{array}{l}\text { Gómez-Peralta \& } \\
\underline{\text { Wolf }(2001)}\end{array}$ \\
\hline & $\begin{array}{l}\text { Jesús del Monte and San } \\
\text { Miguel del Monte, } \\
\text { Michoacán. }\end{array}$ & $\begin{array}{l}\text { Musgo or palmilla } \\
\text { (moss or little palm in } \\
\text { Spanish). }\end{array}$ & $\begin{array}{l}\text { CE: Harvested with Braunia sp. to } \\
\text { be sold for the elaboration of } \\
\text { Christmas nativity scenes in } \\
\text { Morelia, Michoacán. }\end{array}$ & $\begin{array}{l}\text { Gómez-Peralta \& } \\
\underline{\text { Angón-Torres }} \\
(2004)\end{array}$ \\
\hline & $\begin{array}{l}\text { Santa Catarina Lachatao, } \\
\text { Oaxaca. }\end{array}$ & $\begin{array}{l}\text { Musgo (moss in } \\
\text { Spanish). }\end{array}$ & $\begin{array}{l}\text { OR: Used as a decorative plant in } \\
\text { home gardens. }\end{array}$ & $\begin{array}{l}\text { López-Mendoza } \\
\underline{(2020)}\end{array}$ \\
\hline \multirow[t]{4}{*}{ Hypnum spp. } & Oaxaca state. & $\begin{array}{l}\text { Colchoncitos (small } \\
\text { mattresses in Spanish). }\end{array}$ & $\begin{array}{l}\text { CE: To make Christmas nativity } \\
\text { scenes. }\end{array}$ & $\begin{array}{l}\text { Campos-Villanueva } \\
\text { et al. (1992) }\end{array}$ \\
\hline & Oaxaca City, Oaxaca. & & $\begin{array}{l}\text { CE: Sold at the Christmas market } \\
\text { in the Oaxaca city. }\end{array}$ & $\underline{\text { Rees }(1976)}$ \\
\hline & Mexico (country). & & CR: To make bonsai trees. & Glime (2017a) \\
\hline & & & CE: Used in the Christmas period. & $\begin{array}{l}\text { Delgadillo \& } \\
\underline{\text { Cárdenas (1990) }}\end{array}$ \\
\hline \multicolumn{5}{|l|}{ Lembophyllaceae } \\
\hline $\begin{array}{l}\text { Pilotrichella flexilis } \\
\text { (Hedw.) Ångstr. }\end{array}$ & $\begin{array}{l}\text { Miahuatlán de Porfirio } \\
\text { Díaz, Oaxaca. }\end{array}$ & $\begin{array}{l}\text { Musgo (moss in } \\
\text { Spanish). }\end{array}$ & $\begin{array}{l}\text { CE: It is sold in the local market } \\
\text { for Christmas. }\end{array}$ & $\begin{array}{l}\text { Pers. obs. (E } \\
\text { Hernández- } \\
\text { Rodríguez 146, } \\
\text { MEXU) }\end{array}$ \\
\hline \multicolumn{5}{|l|}{ Leucobryaceae } \\
\hline Campylopus spp. & Oaxaca state. & $\begin{array}{l}\text { Musgo (moss in } \\
\text { Spanish). }\end{array}$ & $\begin{array}{l}\text { CE: For the elaboration of } \\
\text { Christmas nativity scenes }\end{array}$ & $\begin{array}{l}\text { Campos-Villanueva } \\
\text { et al. (1992) }\end{array}$ \\
\hline & Oaxaca City, Oaxaca. & & $\begin{array}{l}\text { CE: Sold at the Christmas market } \\
\text { in the Oaxaca city. }\end{array}$ & $\underline{\text { Rees }(1976)}$ \\
\hline
\end{tabular}




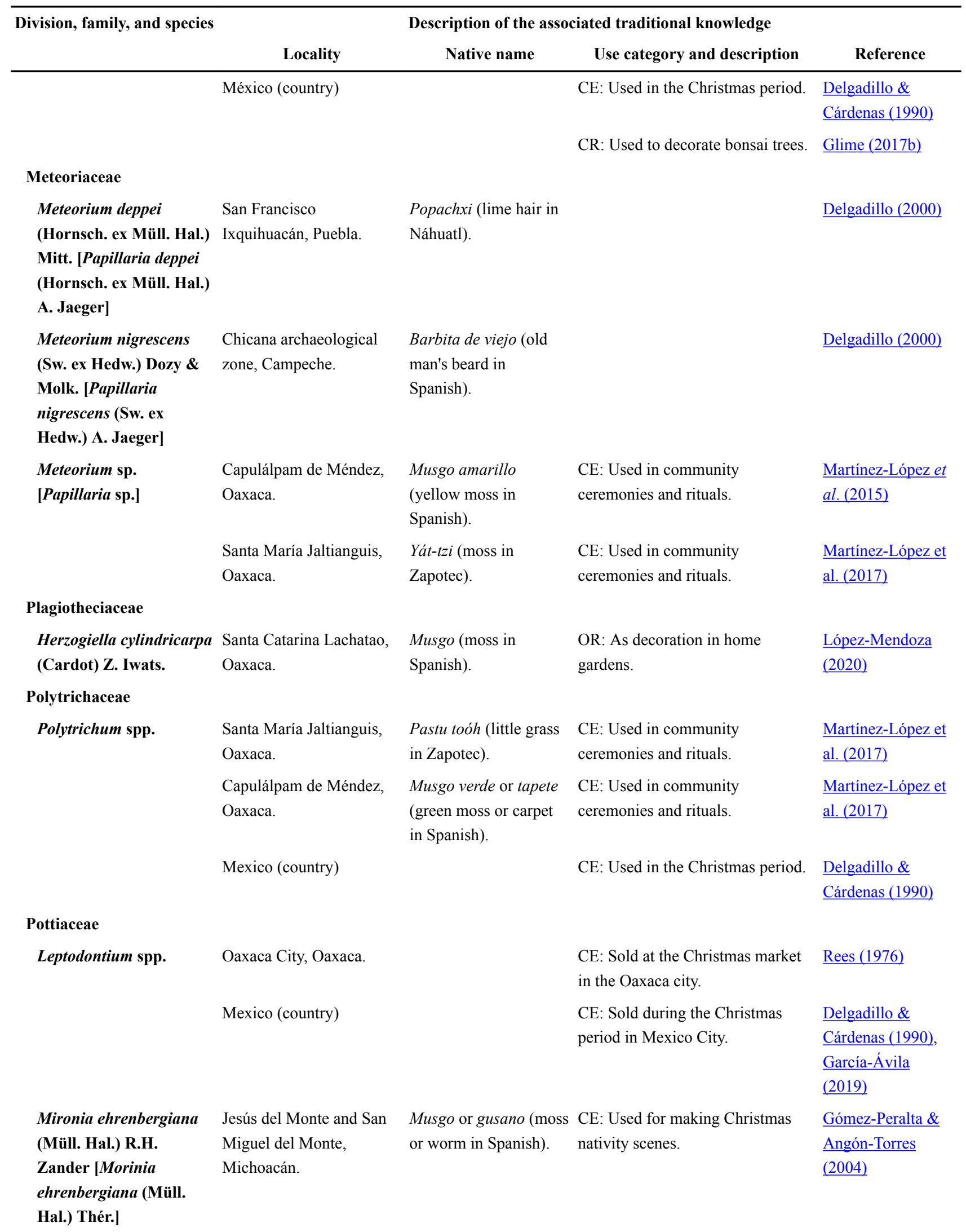




\begin{tabular}{|c|c|c|c|c|}
\hline \multirow[t]{2}{*}{ Division, family, and species } & \multicolumn{4}{|c|}{ Description of the associated traditional knowledge } \\
\hline & Locality & Native name & Use category and description & Reference \\
\hline $\begin{array}{l}\text { Pleurochaete squarrosa } \\
\text { (Brid.) Lindb. }\end{array}$ & San Juan Luvina, Oaxaca. & $\begin{array}{l}\text { Ixxi' chiinku (little } \\
\text { grass in Zapotec). }\end{array}$ & $\begin{array}{l}\text { ME: To prepare tea to relieve } \\
\text { stomachache. Also, it can be boiled } \\
\text { and then placed on a wound } \\
\text { promote healing. }\end{array}$ & $\begin{array}{l}\text { López-Santiago } \\
\underline{(2015)}\end{array}$ \\
\hline $\begin{array}{l}\text { Syntrichia amphidiacea } \\
\text { (Müll. Hal.) R.H. } \\
\text { Zander [Tortula } \\
\text { amphidiacea (Müll. Hal.) } \\
\text { Broth.] }\end{array}$ & $\begin{array}{l}\text { San Francisco } \\
\text { Ixquihuacán, Puebla. }\end{array}$ & $\begin{array}{l}\text { Bopash (trees' hair in } \\
\text { Náhuatl). }\end{array}$ & & Delgadillo (2000) \\
\hline \multicolumn{5}{|l|}{ Pterobryaceae } \\
\hline $\begin{array}{l}\text { Pterobryon densum } \\
\text { Hornsch. }\end{array}$ & $\begin{array}{l}\text { Miahuatlán de Porfirio } \\
\text { Diaz, Oaxaca. }\end{array}$ & $\begin{array}{l}\text { Musgo (moss in } \\
\text { Spanish). }\end{array}$ & $\begin{array}{l}\text { CE: Sold locally at Christmas time. } \\
\text { Unlike other epiphytic species, this } \\
\text { one is sold attached to the branches } \\
\text { on which it grows. }\end{array}$ & $\begin{array}{l}\text { Pers. obs. (E } \\
\text { Hernández- } \\
\text { Rodríguez 125a, } \\
\text { MEXU) }\end{array}$ \\
\hline $\begin{array}{l}\text { Pterobryopsis mexicana } \\
\text { (Renauld \& Cardot) M. } \\
\text { Fleisch. }\end{array}$ & Tlayehualancingo, Puebla. & $\begin{array}{l}\text { Shakuwaki (moss in } \\
\text { Totonaco). }\end{array}$ & & Delgadillo (2000) \\
\hline \multicolumn{5}{|l|}{ Racopilaceae } \\
\hline $\begin{array}{l}\text { Racopilum tomentosum } \\
\text { (Hedw.) Brid. }\end{array}$ & $\begin{array}{l}\text { Sur de Coatepec, } \\
\text { Veracruz. }\end{array}$ & $\begin{array}{l}\text { Puñic (moss in } \\
\text { Popoluca). }\end{array}$ & & $\underline{\text { Delgadillo (2000) }}$ \\
\hline \multicolumn{5}{|l|}{ Sematophyllaceae } \\
\hline $\begin{array}{l}\text { Sematophyllum adnatum } \\
\text { (Michx.) E. Britton }\end{array}$ & Yucatán. & & ME: To prepare medicinal teas. & Glime (2017b) \\
\hline \multicolumn{5}{|l|}{ Stereophyllaceae } \\
\hline $\begin{array}{l}\text { Entodontopsis leucostega } \\
\text { (Brid.) W.R. Buck \& } \\
\text { Ireland }\end{array}$ & $\begin{array}{l}\text { San Blas, Nayarit and } \\
\text { Victoria de Cortazar, } \\
\text { Michoacán. }\end{array}$ & $\begin{array}{l}\text { Flor de Piedra (Stone } \\
\text { flower in Spanish). }\end{array}$ & & $\underline{\text { Delgadillo (2000) }}$ \\
\hline \multicolumn{5}{|c|}{ Thuidiaceae } \\
\hline \multirow[t]{4}{*}{$\begin{array}{l}\text { Thuidium delicatulum } \\
\text { (Hedw.) Schimp. }\end{array}$} & Mexico state. & & $\begin{array}{l}\text { CE: Harvested in forests of the } \\
\text { Nevado de Toluca volcano to be } \\
\text { sold in the Christmas period in } \\
\text { México City. }\end{array}$ & $\underline{\text { García-Ávila }}$ \\
\hline & $\begin{array}{l}\text { Monarch Butterfly } \\
\text { Biosphere Reserve, } \\
\text { Michoacán. }\end{array}$ & & $\begin{array}{l}\text { CE: Sold in the Christmas period } \\
\text { in Morelia, Michoacán. }\end{array}$ & $\begin{array}{l}\text { Gómez-Peralta \& } \\
\underline{\text { Wolf }(2001)}\end{array}$ \\
\hline & $\begin{array}{l}\text { Jesús del Monte and San } \\
\text { Miguel del Monte, } \\
\text { Michoacán. }\end{array}$ & $\begin{array}{l}\text { Musgo or plumilla } \\
\text { (moss or small fine } \\
\text { feather in Spanish). }\end{array}$ & $\begin{array}{l}\text { CE: Sold for Christmas nativity } \\
\text { scenes. }\end{array}$ & $\begin{array}{l}\text { Gómez-Peralta \& } \\
\underline{\text { Angón-Torres }} \\
\underline{(2004)}\end{array}$ \\
\hline & $\begin{array}{l}\text { San Bartolo Oxtotitlán, } \\
\text { Mexico state. }\end{array}$ & & $\begin{array}{l}\text { CE: Harvested in the Christmas } \\
\text { period with other non-timber forest } \\
\text { products such as edible mushrooms } \\
\text { and plants. }\end{array}$ & $\begin{array}{l}\underline{\text { Anastacio-Martínez }} \\
\underline{\text { et al. }(2017 \mathrm{a}}, \underline{\mathrm{b})}\end{array}$ \\
\hline
\end{tabular}


Hernández-Rodríguez et al. / Botanical Sciences 99(1): 13-27. 2021

\begin{tabular}{|c|c|c|c|c|}
\hline \multirow[t]{2}{*}{ Division, family, and species } & \multicolumn{4}{|c|}{ Description of the associated traditional knowledge } \\
\hline & Locality & Native name & Use category and description & Reference \\
\hline \multirow[t]{10}{*}{ Thuidium spp. } & Patamban, Tangancícuaro, & Flor de piedra (stone & CE: Used for making the & Cornejo-Tenorio \& \\
\hline & Michocán. & flower in Spanish). & "Patamban flower carpets", activity & $\underline{\text { Ibarra-Manríquez }}$ \\
\hline & & & related to the Cristo Rey religious & $\underline{(2019)}$ \\
\hline & & & ceremony in October; chosen for & \\
\hline & & & its green color to decorate the & \\
\hline & & & carpets; harvested from pine-oak & \\
\hline & & & forests. & \\
\hline & Santa Catarina Lachatao, & Musgo (moss, in & OR: Used locally as a decorative & López-Mendoza \\
\hline & Oaxaca. & Spanish). & plant in home gardens. & $\underline{(2020)}$ \\
\hline & Mexico (country) & & OR: Used to decorate bonsai trees. & $\underline{\text { Glime }(2017 b)}$ \\
\hline
\end{tabular}

